\title{
Határrendőrség a történelmi Magyarországon 1906-1918
}

A magyar történelemben két ízben hoztak létre határrendőrséget. Az első határrendőrség 1906 és 1918 között teljesített szolgálatot a történelmi Magyarország határain. ${ }^{1}$ A második magyar határrendörség 1945 és 1950 között tevékenykedett. ${ }^{2} \mathrm{Az}$ első magyar határrendőrség a magyar rendőrségek államosításakor ${ }^{3}$, 1919-ben beolvadt a felállításra kerülő Magyar Királyi Állami Rendőrségbe oly mó-don, hogy kezdetben a kerületi rendör-fökapitányságoknak, majd az 1931-től bevezetett szervezetmó-dosítások nyomán — a vidéki fókapitányságnak a közvetlen alárendeltségében tevékenykedtek határ-széli rendőri kirendeltségek elnevezéssel. ${ }^{5}$ Az 1945 és 1950 között tevékenykedő határrendőrséget az Államvédelmi Hatóság létrehozásakor annak kötelékébe helyezték 1950. I. 1-ei hatállyal. ${ }^{6}$ Mindkét magyar határrendőrség alapfeladatát a határforgalom — elsősorban a távolsági határforgalom ellenőrzése alkotta, bár emellett más határőrizeti feladatok ellátásában is részt vett mindkét testület. Mindkét határrendőrség megkísérelte a határvonal őrzését is határrendőr őrsök felállításával. Azonban mindkét kísérlet eredménytelennek bizonyult.

Merőben eltérő volt a két testület létrehozásának időszakában a gazdasági, a társadalmi és a politikai környezet. A dualizmus idejében a Magyar Királyság a térség nagyhatalmának, az Osztrák-Magyar Monarchiának a társországaként meghatározó szerepet játszott a térség viszonyainak az alakításában. Ezzel szemben a II. világháború utáni időszakban Magyarország a Szovjetunió vazallus államává vált. A dualizmuskori határrendőrség létrehozásának nem volt célja a határforgalom visszaszorítása, csupán ellenőrzött viszonyok kialakítása. Ezzel szemben a II. világháború után fokozatosan a határforgalom minimumra redukálása volt a cél. Bár a dualizmus időszaka sem volt mentes a politikai csatározásoktól, azok nem fejlődtek a magyar társadalom egyes rétegei fizikai megsemmisítésének, illetve az élet peremére szorításának a szintjére.

Alapvetően tehát eltért a két időszak rendvédelmi — azon belül pedig a határőrizeti - modellje. A dualizmus időszakában a magyar rendvédelmi modell az úgynevezett kontinentális - azaz a kontinens nyugat-európai országaira jellemző — modellt valósította meg. E modellben a rend védelme két fö pillér-testületen a csendőrségen és a rendőrségeken nyugodott, kiegészítve számos - speciális rendvédelmi szakterületet felölelö — rendvédelmi testülettel. A rendörségek — amelyek polgári örtestületek voltak - a városokban, míg a katonailag szervezett rendvédelmi örtestület, nevezetesen a Magyar Királyi Csendőrség vidéken tartotta fenn a rendet. A „ki-kit győz le?” időszakban ellenben az volt a jellemző, hogy a szovjet államigazgatási modell átvételének a részeként a centralizált és bürokratikus szovjet rendvédelmi modellt építették ki Magyarországon is. ${ }^{7}$

A dualizmus időszakában a magyar határőrizeti modell lényegét az alkotta, hogy a határőrizet valamennyi teendőinek az ellátására nem hoztak létre rendvédelmi testületet, hanem a részhatárőrizeti feladatokat azoknak a rendvédelmi szervezeteknek a határ menti alakulataira bízták, amely szervezetek alapfeladataival harmonizált az érintett részhatárőrizeti teendő. E modell betetőzése volt a Magyar Királyi Határrendőrség felállítása, amely testület — a távolsági határforgalom ellenőrzése mellett - a határőrizeti feladatokat is ellátó szervezetek határörizeti teendőinek a koordinálására volt hivatott. ${ }^{8}$ Ezzel szemben a II. világháború utáni időszakban oly módon szervezték meg a magyar határőrizeti modellt, hogy az kezdetben két szervezeten a határrendőrségen (határforgalom ellenőrzés) és a határőrségen (határvonal őrzése) nyugodott, majd a két szervezetet egy testületben, az Államvédelmi Hatóságban egyesítették, amelynek a feladatköre azonban már lényegesen bővebb volt, mint a komplex határörizet. ${ }^{9}$

Mindkét magyar határrendőrség létrehozását deklaráltan szakmai okokkal indokolták ${ }^{\mathbf{1 0}}$, a felszámolásuk pedig nyilvánvalóan külső nagyhatalmi érdekérvényesítés következménye, azaz a trianoni békediktátum, illetve a magyar közigazgatás szovjet minta szerinti átalakítása volt.

A dualizmuskori magyar határórizeti modell lényegében a korabeli magyar rendvédelmi modell részeként, annak leképezéseként jött létre. A magyar rendvédelmi modell lényege pedig tulajdonképpen már a reformkor közigazgatás fejlesztési vitáiban eldőlt, nevezetesen a rend védelmét alapvetően nem a központi államhatalom kompetenciájába, hanem az önkormányzatok hatáskörébe tartozónak tekintették. ${ }^{11}$ A kiegyezést követően ehhez az elvi állásfoglaláshoz tértek vissza, amelyben minden bizonnyal jelentős szerepet játszott az a körülmény, hogy a gyülölt neoabszolutizmus rendvédelme a központi államhatalomnak közvetlenül alárendelt centralizált modell volt. Már az Olmütz-i alkotmány is rögzítette, hogy „. . . a birodalom belső biztonságának őrzése birodalmi ügy . ..” ${ }^{12}$ A kiegyezéssel viszont egyértelmüen úgy változott a helyzet, hogy a közigazgatás és annak részeként a rend védelme nem tartozott a közös ügyek csoportjába. ${ }^{13}$ Igy tehát megnyílt a lehetősége annak, hogy a reformkorban a municipálisok és a centralisták között zajló elméleti vita hozadékaként szabályozzák a 
Magyar Királyságban a közigazgatás, illetve a rend védelmének a témáját. Ennek megfelelően szabályozták 1870-ben és 1871-ben az önkormányzatok helyzetét, ezen belül pedig a rendőrhatósági jogkört. ${ }^{14}$ Ez a rendvédelmi modell azonban a gyakorlatban megbukott. A leglátványosabb bukás a falvakban következett be. Ennek nyomán vetette fel TISZA Kálmán, hogy — az Európa-szerte diadalútját járó - csendőrséget ismét állítsák fel Magyarországon, de már nem birodalmi testületként, hanem magyar szervezetként. A megvalósított indítvány nyomán vidéken a csendőrség mint a központi magyar államhatalomnak közvetlenül alárendelt katonailag szervezett fegyveres örtestület — vette át a rend fenntartását, kiváló hatásfokkal. ${ }^{15}$

Kézenfekvő volt, hogy a magyar határörizetbe — amely ugyanazoknak a körülményeknek a hatásaitól gyengélkedett, mint a teljes magyar rendvédelem - vonják be a leghatékonyabb magyar rendvédelmi testületet a Magyar Királyi Csendőrséget.

Igaz ugyan, hogy - mivel az Osztrák Császárság és a Magyar Királyság között 10 évente felújított vámszövetség müködött, ezért — az Osztrák-Magyar Monarchia két társországa között bárki, bárhol, bármikor átléphette a határt, azonban az úgynevezett külső határok útlevél- és vámkötelesek voltak. ${ }^{16}$ Az Osztrák-Magyar Monarchia külső határa a Magyar Királyság határaival pedig a magyarromán és a magyar-szerb határ tekintetében estek egybe. Ezt a határt tehát őrizni kellett. ${ }^{17}$

Ennek a határnak a hossza $833,2 \mathrm{~km}$., illetve $458,26 \mathrm{~km}$. volt, összesen tehát 1291,46 km-t tett ki. ${ }^{18}$ A magyar-román határ hegyi határ volt, ahol lényegében a hágókat kellett elsősorban ellenőrzés alatt tartani. A magyar-szerb határ pedig vízi határ volt, meglehetösen mocsaras területen, ahol pedig döntően a mocsáron átvezetö ösvényeket, csatornákat kellett ellenőrizni. Alapvetően tehát nem volt nehezen ellenőrizhető egyik határszakasz sem, amely a határok természetes jellegéből fakadt.

A határőrzés klasszikus hármas feladatkörét, azaz a határvonal őrzését, a határforgalom ellenőrzését és a határrend betartatását különböző szervezetek látták el. A határvonal örzését a Magyar Királyi Pénzügyőrség határ menti szakaszai, a határforgalom ellenőrzését a határ menti városok önkormányzati rendőrségeinek személyi állományaiból kikülönített csoportok, a határrend betartatását pedig az útlevélköteles határszakasszal rendelkező határszéli járások határ menti szolgabírói kirendeltségei végezték. Kezdetben tehát a dualizmuskori Magyar Királyság útlevélköteles határszakaszain mintegy 450 fönyi pénzügyőr, valamint a határátkelőhelyeken - a korabeli szóhasználattal a határkapukon — néhány fös rendőri csoportok, végül pedig a szolgabírói kirendeltségek végeztek határőrizeti teendőket. A rendőrök azonban kizárólag a forgalom ellenőrzésével foglalkoztak. A szolgabírói kirendeltségek munkatársai pedig — civil tisztviselők lévén - fegyveres szolgálat végzésére teljességgel alkalmatlanok voltak. A határőrizeti teendőket ellátó szervezetek pedig két tárcához, a belügyihez és a pénzügyihez tartoztak. A konkrét határörizeti feladatok pedig megoszlottak az önkormányzati szervezetek — azaz a határszéli szolgabírói kirendeltségek és az ugyancsak önkormányzati kompetenciába tartozó határ menti rendőrségek kikülönített csoportjai - valamint a kormány közvetlen irányítása alatt álló polgári fegyveres őrtestület a Magyar Királyi Pénzügyőrség határ menti csapatai között. ${ }^{19}$

Ilyen körülmények között a rendelkezésre álló élőerő hatékony felhasználása is meglehetősen sok kívánnivalót hagyott maga után. Az önkormányzat orientált határőrizet nem bizonyult hatékonynak, hasonlóan a magyar rendvédelmi modell egészéhez. A magyar határőrizetet meg kellett erősíteni. A kormány a legkézenfekvőbb megoldást választotta, a legkiválóbb magyar rendvédelmi testülettel a Magyar Királyi Csendőrséggel erősítette meg a magyar határörizetet oly módon, hogy a csendörségen belül - a mai szóhasználattal éve - szakszolgálatot hozott létre határszéli csendőrség elnevezéssel 1891-ben. ${ }^{20}$ Az átszervezés nyomán a magyar-szerb határon 42 őrsön 149 fő csendőr, a magyar-román határon pedig 21 örsön 171 fö csendör látott el határőrizeti szolgálatot is a közrendvédelmi teendői mellett. A két útlevélköteles határszakasz őrzését tehát összesen 63 csendőr őrsön 320 fő csendőr valósított meg. Ily módon a határvonal őrzése kétlépcsőssé vált (pénzügyőrség 450 fővel és csendőrség 320 fővel) a határ őrzésében résztvevő fegyveres élőerő pedig szinte a duplájára nőtt azaz 450 főről 770 före. ${ }^{21}$

Ez a létszámgyarapítás és annak következtében kialakult kétlépcsős határörzés kétség kívül hozzájárult a magyar határôrizet eredményességének a növeléséhez. Az eredményesség gyarapodásának pedig egyértelmúen az volt az oka, hogy a határőrizeten belül a központi államhatalomnak közvetlenül alárendelt szervezet súlya nőtt. A határőrzés irányítására specializált szervezeti elemek azonban először a Magyar Királyi Csendőrség erdélyi kerületében tűntek fel. E csendőr kerületnél a határ menti csendőr őrsök irányítása céljából úgynevezett kikülönített törzstiszteket állítottak rendszerbe. A kikülönített törzstisztek a csendőr kerület-parancsnokság kötelékében szolgálatot teljesítő határőrizeti szaktiszt és a határszéli csendőr őrsök között álltak, ily módon csökkentették le a szakirányítás tekintetében az egyébként háromszintủ irányítási rendszert két szintüre. A kikülönített tisztek állomáshelyét úgy jelölték ki, hogy lehetőleg az alárendeltségükbe tartozó határszéli csendőr őrsök földrajzi közép- 
pontjához közelítsenek. A határszéli csendőr őrsök a szakasz-parancsnokságaiknak fegyelmi és anyagi ellátás tekintetében továbbra is az alárendeltségében maradtak. A szolgálatot illetően azonban a kikülönített csendőr tisztek irányítása alá kerültek. ${ }^{22}$

A Magyar Királyi Csendőrséget 1906-ban átszervezték, melynek lényege az volt, hogy a parancsnokságok számát és elhelyezkedését igyekeztek a jelentősen gyarapodott csendőr őrsök számához és diszlokációjához igazítani, mivel rendkívül nagy távolságok alakultak ki az őrsök egy része és a parancsnokságaik között, amely nehezítette a hathatós vezetést. Ez a helyzet pedig úgy alakulhatott ki, hogy a lakosság részéről erős és jogos nyomás nehezedett a belügyi tárcára abban a tekintetben, hogy sokkal több helyre telepítsenek csendör őrsöt. Lényegében tehát a lakosság igénye nyomán gyarapodott a csendör őrsök száma, amelyhez azonban igazítani kellett a parancsnokságokat is. Három új csendőr kerület felállításával az 1903. évi törvény alapján megvalósult az 1906. évi átszervezés, azonban csupán két új csendőr kerület felállítására került sor. Közülük az egyik a nagyszebeni csendőr kerület volt. Az átszervezést elrendelő törvény preambulumában rögzítették, hogy „, A (kolozsvári) I.sz. csendör kerület megosztása útján a VII.sz. csendör kerület-parancsnokságnak Nagyszeben székhellyel való mielöbbi felállitását a helyes vezetés, a hathatós ellenörzés és a fegyelem fenntartásának az érdekében, még különösen azért is felette kívánatos, mert ezen csendör kerület-parancsnokság elsősorban a határszéli közbiztonsági és határörizeti feladatok intenzivebb ellátása, valamint a határrendészeti teendők fejlesztésére hivatott állami közegek hathatós támogatására lenne hivatott." 23

Ugyancsak 1906-ban került sor — a Magyar Királyi Határrendőrség felállítását elrendelő 1903. évi törvényben foglaltaknak megfelelően, a magyar politikai közélet viszonylagos megnyugvását követően - a határrendőrség létrehozására. ${ }^{24}$

A Magyar Királyi Határrendőrség volt a polgári magyar állam történetében az első olyan rendvédelmi testület, amelynek alapfeladatát alkotta a határörizet, bár annak valamennyi részfeladatát nem látta el. A határrendőrség feladatát a határforgalom - elsősorban a távolsági határforgalom ellenőrzése, a határrend felügyelete és a határőrizetben valamilyen formában résztvevő állami és önkormányzati szervezetek határőrizeti tevékenységének a koordinálása és irányítása alkotta. Felállításával az útlevélköteles határszakaszokon müködtetett határkapukhoz a közeli városok önkormányzati rendőrségeitől vezényelt rendörcsoportokat visszarendelték, mivel a határforgalom ellenőrzésének a teendőit a határrendőrök voltak hivatottak ellátni. Ugyancsak megszüntetésre kerültek a határszéli szolgabírói kirendeltségek is, mivel feladatkörüket - a határrend betartatása és a társ határőrizeti szervezetek tevékenységének az összehangolása — a Magyar Királyi Határrendőrség vette át. ${ }^{25}$

A Magyar Királyi Határrendőrség felállításával alapvetően megváltozott a magyar határőrizeti modell jellege. Teljes egészében kikerültek a magyar határőrizeti szervezetek köréből az önkormányzati szervezetek, legalább is a határőrizetben állandó jelleggel résztvevő testületeket illetően. Megmaradt azonban a lehetősége annak, hogy a határrendőrség szükség estén a határ menti önkormányzatok rendvédelmi testületeinek egy részét bevonhassa a határőrizeti teendők ellátásába. A Magyar Királyi Határrendőrség nem a létszámából fakadóan, hanem a jogköre miatt vált a magyar határőrizet vezető testületévé, hiszen létrehozásakor a testület személyi állománya csupán 160 főt tett ki és az I. világháborúig is csupán 451 före nött. ${ }^{26}$

A Magyar Királyi Határrendőrség vezető testülete a Magyar Királyi Belügyminisztériumban felállított határrendőr osztály volt. Alárendeltségébe tartoztak a határrendőr kapitányságok. A kapitányságok pedig — amelyek nem csupán irányító parancsnokságok, hanem a határőrizeti teendők egy részének a végrehajtó szervezetei is voltak - a határrendőr kirendeltségeket irányították, mint a szervezet legkisebb, alapszervezeti egységeit. Emellett 1908 és 1912 között határrendör örsöket is felállítottak a kapitányságok a kirendeltségek alárendeltségében. ${ }^{27}$ (I.sz. melléklet)

A Magyar Királyi Határrendőrség személyi állománya négyféle csoportból állt:

„ »- intézkedő személyzet,

- végrehajtó személyzet,

- kezelő személyzet és végül a

- szolgaszemélyzet csoportjára.

Az intézkedő személyzethez tartoznak a fogalmazói kar tagjai, akik mint hatósági tagok járnak el és a bünügyi nyomozásban önálló intézkedésre vannak feljogosítva.

A végrehajtó személyzethez tartoznak: az oktatói-felügyelö, detektív-felügyelö, polgári biztosok, az altisztek, végül a felügyelöi, írnoki, segédtiszt és biztosi személyzetből azok, akik a nyomozó szolgálatra való kiváló alkalmasságuknál fogva a kapitánysági vezető előterjesztése alapján a 
belügyminiszter által a végrehajtó személyzethez soroltatnak. A végrehajtó személyzet tagjai bünügyi nyomozásoknál, mint rendöri közegek járnak el.

A kezelő személyzethez tartoznak az előbbi csoportba nem sorolt felügyelők, írnokok, hivatali tisztek, hivatali segédtisztek és biztosok, végül a napidíjasok akik az irodai szolgálatot végezik.

A szolgaszemélyzethez tartoztak a valóságos és napibéres hivatalszolgák. « ${ }^{28}$

A mai tiszti rendfokozatnak a fogalmazói karon belüli címek feleltek meg. Legalacsonyabb a fogalmazó-gyakornok volt, őt követte a segédfogalmazó és a fogalmazó, valamint a főfogalmazó. A kirendeltségek élén általában főfogalmazók álltak. A határrendőrség tisztikarán belül törzstiszti rang jellegével bírtak a határrendőr-kapitányok és határrendőr-tanácsosok. A határrendőrség teljes személyi állományát a belügyminiszter nevezte ki a kulcsfontosságú határrendőr-kapitányi és a belügyminisztériumban szolgálatot teljesítő határrendőr tanácsosi beosztások kivételével, ahová az uralkodói jóváhagyás is szükséges volt. (II.sz. melléklet)

A határrendőr tanácsosok az egész határrendőrség szolgálati teendőinek irányítását végezték. A határrendőr-kapitány felelős volt a kapitányság törvényes müködéséért. A kapitányság valamennyi beosztottjának munkakörét a határrendőr-kapitány állapította meg. A kapitányságon belüli áthelyezést ö engedélyezte. A kapitányságok közötti áthelyezések esetében a belügyminiszter jóváhagyása volt szükséges. A fogalmazói személyzet általában irodai munkát végzett, szervezett, irányított a kapitány utasítása szerint. Közvetlenül a kirendeltségvezető illetve kapitány alárendeltségébe tartoztak. A felügyelők végezték a nyomozások gyakorlati végrehajtását és az útlevelek kezelését, őket a detektív felügyelö irányította. Az oktató felügyelő végezte a fogalmazói karon kívüli állomány folyamatos képzését. A polgári biztosok a határrendőr-kapitányság határszakaszának egy részéért voltak felelősek. Mivel egy före több 10 kilométernyi határszakasz jutott munkájukat csak a helyi csendőri erők bevonásával tudták végezni, felhasználva a helyi lakosság azon rétegeit, akik némi díjazás ellenében adatokat szolgáltattak a tudomásukra jutott tiltott határátlépésekre vonatkozóan. A kapitányságok esetében a kapitánysági hivatalvezető, kirendeltségek esetében pedig a kirendeltség vezető közvetlen vezetésével dolgoztak a hivataltisztek, hivatali segédtisztek és az írnokok. Ök irodai munkát végeztek. A kapitánysági hivatal vezetője alá tartoztak az altisztek, akiknek a kézbesítési teendők ellátása volt a feladatuk. A határrendőr-biztosok sorompóőri, az útlevél ellenőrzésre kijelölt helység előtti őrszem, a toloncok és letartóztatott egyének kísérete, a fogoly őrizete, a magasabb rangú határrendőrök szolgálati tevékenységének fegyveres biztosítása, a kisebb irodai munkák végzése és kivételes esetben a kézbesítés lehetett. A szolgaszemélyzet kétkezi munkát végzett, takarítás, fütés stb.

A korabeli képesítési követelmény a határrendőr-kapitányok részére a jogtudori oklevelet írta elő. A határrendőrség tiszti karának a Ludovica Akadémiai, vagy Jogakadémiai végzettséggel kellett rendelkeznie. A jogakadémiai diploma a néhai államigazgatási föiskola diplomája megfelelöjének tekinthető. A felügyelöktől úgynevezett főgimnázium, vagy föreál iskola, illetve ezen középiskolákkal egyenrangú kereskedelmi iskola, vagy katonai iskola végzését követelték meg. A gyakorlatban azonban a tiszti kar döntő többsége jogi végzettséggel, a felügyelők pedig általában gimnáziumi végzettséggel rendelkeztek.

A határrendőrség legénységi állományába a felvételi követelmények között első helyen állt a magyar állampolgárság és a feddhetetlen elöélet, valamint a magyar nyelvnek szóban és írásban való bírása. Felvételi követelmények voltak még a legénységi állomány részére legalább 3 év katonai, vagy csendőri, illetve együttes szolgálat, az egészséges testalkat, a 40 éven túl nem haladott életkor és végül a rendezett anyagi viszonyok. Előnyben részesítették azokat a pályázókat, akik a magyar nyelven kívül valamelyik nemzetiség nyelvét beszélték. A határrendőrséghez pályázókat próbaidőre vettek fel a próbaidő eredményes leszolgálása után véglegesítették őket a határrendőrségnél. A próbaidős határrendőröket először három hónapig tartó tanfolyamra vezényelték. A tanfolyamon a határrendőri szolgálathoz szükséges elméleti tudást sajátítottak el.

»Az elméleti oktatás a következő anyagot öleli fel:

1. a határrendörségre,

2. az útlevélügyre,

3. a kivándorlásra,

4. a külföldiek lakhatására vonatkozó törvények, utasítások és rendeletek,

5. a büntettekre, vétségekre és kihágásokra vonatkozó törvények /csak vázlatosan /,

6. a kihágási eljárás /csak vázlatosan /,

7. a 130 000/1899. (XII. 22.) BM.kr.-el kiadott, rendőri nyomozási utasításnak a határrendőri szolgálatnál szükségelt részei,

8. toloncz szabályzat, 
9. a kapitányságok területének földrajza, különös tekintettel a föbb közlekedési vonalakra,

10. balesetek alkalmával elsősegélynyújtás,

11. jelentések szerkesztése és végül,

12. a fegyverzet ismertetése, használatának módja és karbantartása.« ${ }^{29}$

Az elméleti oktatás végén a próbaidős határrendőrök vizsgán vehettek részt, melyen - tudásuktól függően - igen alkalmas, alkalmas, nem alkalmas elbírálásban részesültek. A nem alkalmas eredménynyel vizsgázókat elbocsátották. Az elméleti vizsga elött a próbaidős határrendőrök nem voltak szolgálatba oszthatók. A vizsga után hat hónapos gyakorlati próbaszolgálatot teljesítettek. A hat hónap letelte után az illetékes kapitányság vezetője előterjesztést tett a belügyminiszternek a próbaidős határrendőr véglegesítésére, vagy elbocsátására, illetve a próbaszolgálat idejének meghosszabbítására.

A véglegesített határrendőrök részére hetenként kétszer minimálisan egy-egy órás ismétlő rendszerezö képzést tartott az oktató felügyelö, vagy a tiszti állomány egy megbízott tagja.

A határrendörök, ha az elméleti vizsgálaton igen alkalmas osztályzatot nyertek két, ha alkalmas osztályzatot nyertek, három évi szolgálat után rendőrbiztosi vizsgára jelentkezhettek, $\mathrm{s}$ ha ezen vizsgát letették öket előjegyzésbe vették az üresedésbe jövő határszéli rendőrbiztosi állásokba, amelyekbe csak közülük lehetett kinevezni az új személyeket." 30

A Magyar Királyi Határrendőrség ezzel a szervezettel és személyi állománnyal látta el feladatát.

A határrendőrség feladatait, a felállítását elrendelő törvény 15 pontban határozta meg:

„a) a határon átkelők figyelemmel kísérése, a határmentén felmerülő, államrendészeti szempontból fontosabb mozzanatokról és eseményekről tájékozás szerzés és az észlelteknek az illetékes hatóságokkal való közlése;

b) a külföldiek bejelentésére és lakhatására vonatkozó szabályok végrehajtása;

c) a kémkedés megakadályozása, esetleg a kémek letartóztatása;

d) a szomszédos állam lakó részéről személyek és tárgyak ellen jöhető erőszakos támadás meggátlása, különösen pedig a katonai védmüvek, az ország határának megjelölésére szolgáló határjelek, jelzők katonai vagy polgári hatóságok által felállított földmérési jelek megrongálásának, megsemmisítésének vagy megváltoztatásának megakadályozása és feljelentése;

e) kitiltott, rendőri kifogás alá eső és magukat igazolni nem tudó egyének az állam területére belépésben megakadályozása;

f) nyomozott, vagy valamely bűntető cselekménnyel gyanúsított $s$ a törvények vagy a fennálló szabályok értelmében előzetesen letartóztatható egyéneknek a határszélen való letartóztatása;

g) a határszélen letartóztatott a toloncz szabályok rendelkezései alá eső egyének eltoloczolása, külföldről érkező tolonczok átvétele és tovább indítása;

h) fegyverek, lőszerek és hadiszerek ki- vagy bevitelének ellenőrzése, valamint tilalom esetén ilyenek és más tárgyak kivitelének és behozatalának megakadályozása;

i) hadköteles egyének kiszökésének megakadályozása;

j) nőcsempészet meggátlása;

k) határszéli vasúti és gőzhajó állomásokon az államrendőri és közbiztonsági teendők ellátása s a közegészségügyi szabályok betartásának ellenőrzése;

1) határszélén lévő szállodák, vendéglők, korcsmák, kávéházak és egyéb nyilvános helyek ellenőrzése;

m) azon határvonalon, hol útlevél kötelezettség áll fenn az útlevek vizsgálata, határátkelési igazolványok kiállítása;

n) az útlevél szabályok áthágása, tilos visszatérés, nőcsempészés, a külföldiek bejelentése és lakhatására vonatkozó szabályok megszegése által elkövetett kihágások eseteiben I. fokon való rendőri bíráskodás;

o) a csempészet megakadályozásában való közremüködés és az erre hivatott közegek támogatása."31

A határrendőrség müködését részletesen belügyminiszteri utasítás szabályozta, mely tartalmazta a hatóság célját, szervezetét és a határmenti közbiztonság teendőit. A határrendőrség müködésére is vonatkozó utasítás 77 oldalon, 7 fejezetből és 117 paragrafusból állt, mely - a kor színvonalán teljes részletességgel - tárgyalta egy fegyveres államhatalmi szerv müködésének szabályait. Lényegében a mai értelemben vett szolgálati szabályzat elődjének tekinthető. Mivel ebben az időben a rendőrséget egészében még nem államosították és az első központilag irányított országos hatáskörủ rendőri szervezet a határrendőrség volt, bizton állítható, hogy ez a miniszteri utasítás lényegében az állami keretek közt működő rendőrség első szolgálati szabályzatának tekinthető. Az utasítás első fejezete a határrendőrség szolgálati jellegü teendőivel, a második fejezete a határrendőrség illetékességével és más hatóságokhoz fúződő viszonyával, a harmadik fejezete a határrendőrség szervezetével, a negyedik 
fejezet a határrendőrség eljárásánál irányadó joggyakorlat alkalmazásával és a határszéli rendőrkapitányságok vezetésével, a belső ellenőrzésével, valamint a fegyverhasználattal, az ötödik fejezet a fegyelmi eljárással, a hatodik fejezet az ügyvitellel, mely alatt elsősorban a hivatalos okmányok bürokratikus jellegü kezelését értették, a hetedik fejezet a pénz és egyéb értékek kezelésével foglalkozott. ${ }^{32}$

Az utasítás fejezeteit átvizsgálva képet kaphatunk az Osztrák-Magyar Monarchia magyarországi határrendőrségének állapotáról. A szolgálati teendők ellátása terén nagy jelentőséget tulajdonítottak az államellenes izgatást tartalmazó nyomtatványok csempészésének, a kémkedés megakadályozásának. Bizonyára érdekességként hat a mai emberre, hogy a határrendőrség feladata volt - a katonai galambposta állomásokon lévő madarak kivételével - a postagalambok összeírása és figyelemmel kísérése is. A kor szomorú realitása volt a tömeges kivándorlás. Ezt az állam nem gátolta, azonban a határon az engedély nélküli az úgynevezett titkos ügynökök által történő átjutás megakadályozása külön feladatként jelentkezett. A polgári biztosok olyan hatalmas határszakaszokkal rendelkeztek, melyet nem tudtak kielégítően átfogni. A határon számtalan titkos út, ösvény vezetett keresztül. Ha egy titkos kivándorlási ügynököt sikerült elfogniuk rövid időn belül más utakon, más ügynökök szervezték az illegális kivándorlást. A határforgalom jellegére enged következtetni az is, hogy megtiltották a szerb majom- és medvetáncoltatók Magyarországra történő bebocsátását. A határrendőrség közegeinek különös figyelmet kellett fordítani arra is, hogy a kivándorlás leple alatt rejtőző leánykereskedőket elfogják. ${ }^{33}$

A határrendőrségnek - mint határőrizeti szakszervnek - fő feladata a határforgalom ellenőrzése volt. Ennek során úgynevezett kül- és belszolgálatot látott el. Külszolgálat alatt értették azt a szolgálatot, amit szabadban vagy járművön teljesítettek, belszolgálatnak pedig az épületben végzett hivatalos elfoglaltságot tekintették. A külszolgálat nemei voltak:

„I. Portyázó / mozgó /,

II. Állószolgálat / helyi / és

III. Mozgó vonat / hajó / ellenőrzés.

Portyázó szolgálat alatt a következő szolgálatok értendők: Vezénylések, helyettesítések alkalmával a ténylegesen útban eltöltött napok áthelyezési, fogolykísérési és az állomás helyétől legalább 6 $\mathrm{km}$ távolságot meghaladó mindennemü oly szolgálat, amely az álló szolgálat fogalma alá nem tartozik.

Állószolgálat a távolság figyelmen kívül hagyásával a következők értendők: vezénylés / helyettesítés /, határkapunál, vasúti, hajóállomásnál, csónak-, kompátkelési helynél, továbbá az állomáshelytöl 6 km-en belül teljesített mindennemü külszolgálatot.

Mozgó vonat / hajó / ellenőrzése alatt mindennemü a mozgó vonaton / hajón / teljesítendő szolgálat értendő." ${ }^{, 34}$

A határrendőrség tagjait - szolgálatuk ellátása során - fegyverhasználati jog illette meg, melynek keretében joguk volt fegyvert használni:

"1. Jogos védelem gyanánt, a tettes veszélyesen megtámadtatik;

2. ha életét vagy testi épségét komolyan fenyegető támadással oly körülmények között fenyegettetik, hogy annak bekövetkezésétől alaposan tarthat;

3. a szolgálat teljesítése közben olyan tettleges ellenszegülésre talál, mely azt meghiusítaná s az ellenszegülés legyőzésére már alkalmazott minden kíméletes eszközt sikertelen maradt;

4. ha a fegyver használata életükben vagy testi épségükben támadott harmadik személy megmentésére vagy megvédésére szükséges." 35

„A határrendőrség a hírszerző, operatív munka segítéséből is kivette a részét. A határrendőr-kapitányságokat és kirendeltségeket ellátták az elhárítás által felfedett külföldi hírszerzö ügynökök listájával. Útlevél ellenőrzések alkalmával a listán szereplő személyeket vagy letartóztatták, vagy a határrendörség nyomozói megkezdték a figyelésüket, amit később a budapesti rendőrségnek vagy más szerv illetékeseinek adtak át. De nem csak elöre meghatározott személyek felbukkanása esetén folytattak figyelést, kiterjesztették tevékenységüket mindenkire, akit gyanúsnak találtak, de letartóztatásához nem rendelkeztek megfelelö alappal.

Az ellenséges hírszerzők kiszürése mellett segítséget nyújtottak a közös hadsereg felderítő osztályainak ügynökök szervezéséhez is. A területileg illetékes hadtest törzs felderítő osztályának tisztjét értesítették azon személyekről, akik a határon rendszeresen átjártak és véleményük szerint alkalmasak voltak információ szállítására a felderítő osztály és a szomszédos országba telepített rezidentura között. A katonai elhárítás, a felderítő munka eredményes segítségének honorálásaként a Császári és Királyi Hadsereg hadtest törzsei mellett müködő felderítő osztályok vezetői több ízben 
tettek javaslatot határrendőr-kapitányságok és kirendeltségek vezetőinek legmagasabb szintű elismerésére.

A határrendőrség is végzett felderítés. Egyrészt megkísérelték kikérdezni a határon átkelő utasokat, másrészt megbíztak egyes személyeket, hogy a határ túloldalán a lakosság hangulatát, a közlekedési és hírközlő hálózatot, valamint az ott található katonai, határőrizeti erőket kipuhatolják. Ennek során egyes esetekben sor került a határ mentén szolgálatot teljesítő szerb vagy román hivatalnokok, vasutasok, katonák stb. lepénzelésére és beszervezésére.

A határrendőrség feladatát képezte még a határátkelő helyen be- vagy kilépő fontosabb személyek, az uralkodóház tagjai stb. személyi biztonságának szavatolása is. A biztosítási feladatokat a csendőrséggel szorosan együttmüködve hajtották végre, mert a csendőrség feladata volt a határállomástól az ország belseje felé az exponált személyek menetvonalának biztosítása." ${ }^{\$ 36}$

A Magyar Királyi Határrendörségnek összetett szolgálati feladatai voltak, melyet nem tudott volna a társ rendvédelmi testületek bevonása nélkül eredményesen ellátni. Ezért kiterjedt jogosultságokkal is felruházták a társ szervezeteket illetően.

A Magyar Királyi Határrendőrség viszonya a vármegyei közigazgatáshoz és a társ fegyveres testületekhez sajátos volt. Szolgálati tekintetben a határrendőrség közvetlenül a belügyminiszter alárendeltségébe tartozott. Azonban a határrendőr kapitányságok területileg illetékes vármegye főispánjának, a kirendeltségek pedig a szolgabíráknak a határőrizettel kapcsolatos - korabeli szóhasználattal élve megkereséseit kötelesek voltak végrehajtani. Az illetékességet a határrendőrség maga döntötte el. Ha a határrendőrség és a helyi közigazgatás illetve rendőrhatóság között mégis hatásköri nézeteltérésre került sor abban a belügyminiszter döntött. Az államszervezet hierarchiájában határrendör-kapitány a vármegyei főszolgabíróval illetve a városok rendőrkapitányaival állt azonos szinten. Az a gyakorlat érvényesült, hogy a határrendőrség müködése során észlelt, nem a határrenddel kapcsolatos törvényellenes cselekedeteket az arra illetékes hatóságoknak, más hatóságok pedig az általuk észlelt és a határrendre vonatkozó törvénysértéseket a határrendörségnek jelezték. E mellett a bünügyi nyomozásra vonatkozó belügyminisztériumi rendelet a határrendőrségre is vonatkozott, amely alapján köteles volt a bíróságok és ügyészségek felhívásának eleget tenni, a büntetendő cselekmények kinyomozásában részt venni. ${ }^{37}$

A határrendőrség és a helyi rendőrhatóságok együttmüködése alapvetően két területre osztható.

Egyes - a határrendőrség hatáskörébe tartozó - esetekben a határrendőr-kapitányság müködési területén lévő városok rendőrsége köteles volt automatikusan mindenfajta megkeresés, felszólítás, átirat nélkül is eljárni és arról az ügy jellege szerint azonnal, vagy havonta jelentést tenni a határrendörkapitánynak. Ilyenek voltak:

a./ kémkedés;

b./ fegyverek, löszerek szállításának;

c./ hadkötelesek kiszökésének;

d./ nőcsempészetnek és;

e./ csempészetnek a megakadályozása valamint;

f./ határszéli nyilvános helyek ellenőrzése.

Amennyiben az adott város határának az ország határával volt közös határszakasza a városi rendőrség köteles volt még:

a./ kitiltott illetve gyanús személyeknek az országba történő bejutását illetve a;

b./ büntetőeljárás alatt álló személyeknek az országhatáron a kijutását megakadályozni és;

c./ a külföldi tolonczokat átvenni illetve a helyi tolonczokat elszállítani.

A városi rendörségek kötelesek voltak még külön felszólításra:

a./ a határrendörség részére adatokat szolgáltatni;

b./ a határrendőrség megbízásából nyomozást folytatni;

c./ a határrendörség részére erőket és eszközöket biztosítani, amennyiben a kérdéses ügyek a határrenddel összefüggésben álltak.

Sürgős esetben a városi rendőrkapitányságoknak el kellett tekinteni a határrendôr-kapitányság írásos megkeresésétől és a határrendőrség tisztjének szóbeli felhívásra is el kellett végezni ezen teendőket.

Lényegében a rendőrséggel megegyező volt a csendőrséghez füződő viszony is. A határrendőrkapitányságok müködési területén lévő csendőrség köteles volt támogatni a határrendőrséget:
a./ karhatalom nyújtásával;
b./ megfigyelés végrehajtásával és
c./ nyomozásokban segéderő biztosításával. 
A határrendőr kapitány felszólításakor a csendőrségnek a csendőrség szolgálati szabályzatának a vármegye főszolgabírókra, vagy a városi rendőr-kapitányokra vonatkozó részét kellett alkalmaznia. A korabeli határrendőrség tehát a társ fegyveres testületek irányában is jelentős jogokkal felruházott szerv volt. ${ }^{38}$

A határrendőrség müködési területe általában - a határtól számított - megközelítőleg $40 \mathrm{~km}$-es területsávra terjedt ki. A határőrizettel kapcsolatos nyomozati tevékenységet azonban a határrendőrség müködési területén köteles volt végezni. A határrendörség müködési területét és diszlokációját 41 rendelettel módosították, szinte valamennyi rendelet a müködési terület bővítésére irányult. Egyes kapitányságok müködési területe nem csak a határmenti vármegyéket, hanem több - a határvonallal nem érintkező - vármegyét is magába foglalta. A határrendőrség megalakulásakor müködési területe 25 vármegyére, az Osztrák-Magyar Monarchia összeomlásakor pedig 30 vármegyére terjedt ki. ${ }^{39}$

A Magyar Királyi Határrendőrség kiterjedt hatáskörrel rendelkezett. Összességében — nem számítva a határ menti önkormányzati rendvédelmi szervezetek határőrizet orientált feladatainak az ellátását - hétféle szervezet (csendőrség, pénzügyőrség, vámhivatalok, vesztegintézetek, egészségügyi állomások, révhivatalok, erdőhatóságok) határőrizettel összefüggő tevékenységét koordinálta a határrendőrség. A hét szervezet közül azonban csupán a csendőrség és a pénzügyőrség tekinthető fegyveres szervezetnek. A határ menti erdőhatóságok tagjai ugyan rendelkeztek vadászfegyverrel, azonban rájuk csak esetlegesen lehetett számítani, mivel feladatuk csupán arra szorítkozott, hogy amennyiben az erdőjárásuk során gyanús idegenekkel találkoztak azokat a legközelebbi hatósághoz előállítsák. A vámhivatalok, a vesztegintézetek — a határforgalomban résztvevő mezőgazdasági termékek vizsgálatában résztvevő szervezetek - az egészségügyi állomások, mint a határforgalomban résztvevő személyek orvosi felügyeletét ellátó szervezetek, továbbá a révhivatalok nem voltak felfegyverezve. Ezeknek az intézményeknek a munkatársaira tehát csak mint szakhatósági személyzetre lehetett támaszkodni. Az igazsághoz azonban az is hozzátartozik, hogy a vámhatár menti pénzügyőr szakaszok kötelékében szolgálatot teljesítő pénzügyőrök és a határszéli csendőrség személyi állományába tartozó csendőrök sem tekinthetők teljes értékü határőrizeti szolgálatot ellátó személyzetnek, mivel a müködési területükön nem csak határőrizeti szolgálatot teljesítettek, hanem a testület alapfeladatának az ellátásából fakadó szolgálati teendőket is meg kellett valósítaniuk ugyanúgy, mint ahogyan azt a testületüknek az ország belsejében szolgálatot teljesítö tagjai is tették. Mindent egybevetve a történelmi Magyarország határain fegyveres és fegyvertelen személyeket is figyelembe véve mintegy 3000 személy látott el valamilyen határőrizeti feladatot, melynek az összefogása és irányítása a határrendőrség feladatát alkotta. ${ }^{40}$ (III.sz. melléklet)

A dualizmuskori magyar határőrizeti modell eljutott az önkormányzati meghatározottságú szisztéától a központi államhatalom által közvetlenül irányított határőrizeti formáig. Ezzel azonban a folyamat még nem zárult le, mivel a határrendőrség és a határszéli csendőrség együttmüködésében disszonanciák keletkeztek. Mindkét testület képviselöi számos panasszal éltek a közös irányító tárcánál. A határrendőri panaszok lényege az volt, hogy a határ menti csendőrég vonakodik végrehajtani az intencióikat. A határszéli csendőrség képviselői pedig arra panaszkodtak, hogy a határrendőrség szolgálati elöljáróikat figyelmen kívül hagyva szeretné a határszéli csendőröket utasítani. ${ }^{41}$

A belügyi tárca előtt két lehetséges megoldási alternatíva állt. Az egyik az lett volna, hogy valamennyi határőrizeti részteendőt - azaz a határforgalom ellenőrzése és a határrend felügyelete mellett a határvonal őrzését is - egy szervezetben, a Magyar Királyi Határrendőrségben koncentrálja. Minden bizonnyal ez lett volna a költségesebb és a kevesebb eredményességgel kecsegtető megoldás, mivel - 1908 és 1912 között a határrendőr örsök felállítása és müködtetése nyomán — bebizonyosodott, hogy a határrendőr őrsök hatékonysága meg sem közelíti a határszéli csendőr őrsökét. Éppen ezért szerette volna a határrendőrség ezen őrsöket minél szorosabban az ellenőrzése alá vonni. A másik megoldás pedig az volt, hogy a kialakult határőrizeti modellt úgy müködtetik, hogy az abban résztvevő szervezetek - elsősorban a határszéli csendőrség és a határrendőrség — feladatait markánsan és egyértelmüen elhatárolják. Ez a megoldás tünt a takarékosabb és eredményesebb útnak. A döntést megelőzően a Magyar Királyi Csendőrség OLÁH Ödön vezetésével tiszti delegációt küldött ki az Osztrák Császárság örökös tartományaiba, illetve Bosznia-Hercegovinába azzal a céllal, hogy tanulmányozzák az ottani csendőr szervezetek határörizeti teendőkben való részvételének a tapasztalatait. A tanulmányút jelentésében megfogalmazottakat pedig az átszervezés során vették figyelembe. ${ }^{42}$

1912-ben a határrendőrség és a határszéli csendőrség együttmüködését újraszabályozták, melynek során jól elkülönítették a két testület határőrizeti hatásköreit. Egyértelművé tették, hogy a határszéli csendőrség személyi állományát mely esetekben, milyen feladatokra és kizárólag a tisztjeik által lehet igénybe venni. ${ }^{43}$ 
E szabályozás keretében terjesztették ki a határszéli csendőrségnél a speciális vezetési elemet jelentő kikülönített törzstiszti rendszert a délvidéki határszéli csendörség csapataira is, valamint bevezették a nyári őrsöket, továbbá módosították a határszéli csendőrség szolgálatellátásának a jellegét is, egyben pedig megemelték a határszéli csendőrség létszámát. ${ }^{44}$

A Magyar Királyi Határrendőrség 13 éves fennállása során még egy változást élt meg, nevezetesen a katonai határőrizet időszakát. Háború esetén tért át a magyar határőrizet a valószínüsíthetően hadműveleti területté váló határ menti térségekben a katonai határőrizetre. Ez azért volt érdekes jelenség, mert a Magyar Királyságban a kivételes hatalom időszakát - a közös haderő többszöri sürgetése nyomán - 1912-ben az Osztrák Császárságétól eltérő módon szabályozta a magyar országgyülés. Magyarországon ugyanis — ellentétben az Osztrák Császársággal, ahol a porosz mintát követték — a brit szisztémát követték, tehát az alkotmányos emberi jogok korlátozásának a kivitelezője nem a haderő volt, hanem a polgári kormány. Ebből fakadóan pedig a Magyar Szent Korona alárendeltségébe tartozó területeken a rendvédelmi testületek nem kerültek a haderő felügyelete alá, hanem a kormány kompetenciájában maradtak. ${ }^{45}$

Ettől az általános magyarországi szabályozástól azonban eltért a hadmüveleti területek helyzete, mivel ott az irányítás mindenképp a haderő kezébe került. Az előzetes tervek szerint valószínüsíthető hadmüveleti területként a magyar-szerb és a magyar-román határvidék kerülhetett szóba. A területileg illetékes hadtest-parancsnokságok vezérkari osztályai ki is dolgozták a katonai határőrizetre való áttérés tervét, melynek részleteit a terepen egyeztették az érintett határőrizeti szervezetek képviselöivel. A katonai határőrizet időszakában az érintett határ menti térségekben a magyar határőrizet vezetö testülete már nem a határrendőrség, hanem a határszéli csendőrség volt. A határrendőrséget ugyanis a személyi állomány felkészültsége, felszereltsége és az elhelyezési körülményei nem tették alkalmassá arra, hogy a katonai határőrizetre történő áttérést levezényelje. A katonai határőrizetre áttérés ugyanis azt jelentette, hogy a haderő határra történő felvonulásáig — amely elöreláthatóan mintegy két hetet vehetett igénybe - a határőrizeti erőknek biztosítaniuk kellett a határra vezető közlekedési infrastruktúra használhatóságát és a határ mentén a jelentős befogadóképességü épületek védelmét az ellenséges támadásokkal szemben, illetve arra kellett törekedni, hogy a lehetőségek függvényében a túloldali hasonló mütárgyakat megrongálják. Ennek érdekében a katonai határőrizet bázisává a határszéli csendőr őrsöket fejlesztették. Ennek során növelték az örsök befogadóképességét, futóárkot és tüzelöállásokat létesítettek az őrsök körül, melyeket drótakadályokkal erösítettek meg, továbbá a rendszeresített lőfegyverek hatásos lőtávolságán belül megtisztították a kilátást, illetve kilövést akadályozó növényzettől a terepet. A környék hadra fogható férfi lakosságát ezen örsökre hívták be mozgósítás elrendelésekor és a felszerelésüket is helyben tárolták. Ily módon érték el azt, hogy kellő számú élőerő álljon rendelkezésre a katonai határőrizeti feladatok ellátására. Ebben az időben már 6-8 fős járőröket kellett vezényelni valamint vonalszakasz őrségeket és mobil tartalékokat kellett létrehozni a közlekedési útvonalak őrzése és a fontosabb mütárgyak védelme érdekében. ${ }^{46}$

A katonai határörizetre történő áttérést azonban csak azokon a határszakaszokon készítették elö, ahol valószínüsíthető volt a térség hadmüveleti területté válása. Azokon a határszakaszokon, amelyek nem váltak hadmüveleti területté háború időszakában is a Magyar Királyi Határrendörség maradt a magyar határőrizet vezető testülete. A fegyverletételt követően a történelmi Magyarország jelentős részének a megszállásakor a Magyar Királyi Határrendőrség lényegében megszünt, mivel előírás szerint az ország belsejébe vonuló magyar haderő csapataihoz csatlakozva elhagyta szolgálati helyét. Azokon a határszakaszokon azonban, amelyeket nem szállt meg idegen haderö a határrendőrök a helyükön maradtak. Ök képezték a magját az 1919-ben államosított magyar rendőrség határszéli kirendeltségeinek, amelyeknek a feladatát azonban már nem a határőrizet irányítása, csupán a határforgalom ellenőrzése képezte. $^{47}$

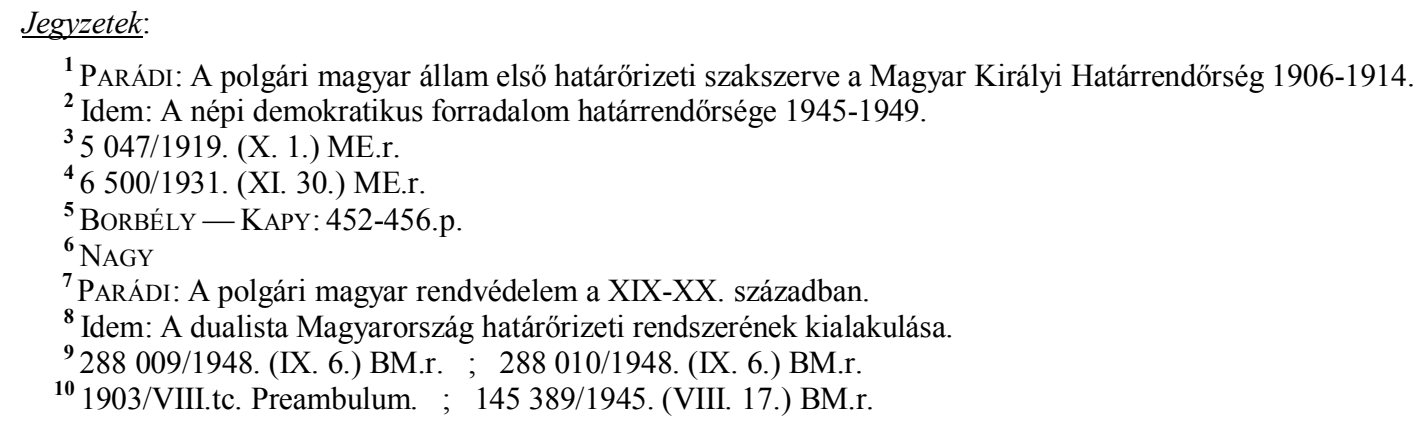


${ }^{11}$ CSIZMAdia: 79.p.

${ }^{12}$ A neoabszolutizmus birodalmának 1849. III. 4-én engedményezett = octrojált (oktroyierte) alkotmánya, az úgynevezett olmütz-i alkotmány.

Nr.150/1849.

13 1867/XII.tc.

${ }^{14}$ 1870/XLII.tc. ; 1871/XVIII.tc.

${ }^{15}$ PARÁDI: A Magyar Királyi Csendörség. Az elsö magyar polgári központositott, közbiztonsági örtestület 1881-1945. 32-42.p.

16 1867/XII.tc. op.cit. ; 1867/XVI.tc. ; 1878/XX.tc. ; 1887/XXIV.tc. ; 1898/I.tc. ; 1899/XXX.tc. ;

1908/XII.tc. ; GALÁNTAI:28-51.p.

${ }^{17}$ PARÁDI - SUBA - VEDÓ: 50-56.p.

${ }^{18}$ SUBA: 25.p.

${ }^{19}$ PARÁDI: Pénzügyörség és vámhivatalok a határörizetben. 51-53.p.

${ }^{20} 50$ 431/1891. (VII. 1.) BM.r.

${ }^{21}$ PARÁDI: Csendörség a határörizetben. 58-59.p.

${ }^{22}$ PARÁDI: A Magyar Királyi Csendőrség határörizeti szolgálata.

23 1903/VII.tc.

24 1903/VIII.tc. op.cit. ； 5695/1905. (XII. 29.) ME.r. ; 91 000/1905. (XII. 29.) BM.kr.

${ }^{25}$ PARÁDI: A Magyar Királyi Határrendőrség a magyar határőrizet szakmai vezető testülete.

${ }^{26}$ A testület 1905. X. 11-ei hatállyal kinevezett személyi állománya volt: 11 fö határrendör kapitány, 18 fő határrendőr fogalmazó, 9 fö határrendőr segédfogalmazó, 10 fö határrendőr fogalmazógyakornok, 19 fő határrendőr felügyelö, 11 fő határrendőr hivatali segédtiszt, 50 fö határrendőr biztos és 22 fő hivatalszolga, összesen: 150 fö.

PARÁDI: Rendörség a határörizetben. 37.p.

${ }^{27}$ PARÁDI: A dualizmuskori magyar rendvédelem és határőrizet. A Magyar Királyi Határrendőrség.

${ }^{28} 58$ 320/1912. (IV. 13.) BM.kr.

${ }^{29} 128$ 000/1906. (1907. I. 3.) BM.kr.

${ }^{30}$ PARÁDI: Rendörség a határörizetben. op.cit. 48-50.p.

31 1903/VIII.tc. op.cit. 2. §

3291 000/1905. (XII. 29.) BM.kr. op.cit.

${ }^{33}$ PARÁDI: Rendörség a határörizetben. op.cit.

${ }^{34} 66$ 733/1910. (VII. 1.) BM.kr.

35128 000/1906. (1907. I. 3.) BM.kr. op.cit.

${ }^{36}$ PARÁDI: Rendörség a határörizetben. op.cit. 40-41.p.

${ }^{37}$ Loc.cit. 53.p.

${ }^{38}$ Idem: A polgári magyar állam első határőrizeti szakszerve a Magyar Királyi Határrendőrség 1906-1914. op.cit.

${ }^{39}$ Idem: Rendörség a határörizetben. op.cit. 47.p.

${ }^{40}$ Idem: Pénzügyörség és vámhivatalok a határörizetben. op.cit. 51-53.p. ; Idem: Rendörség a határörizetben. op.cit. 252.p.

${ }^{41}$ Idem: A csendőrség teendői az Osztrák-Magyar Monarchia Magyar királysága külső határainak őrzésében.

42 Idem: Az Osztrák-Magyar Monarchia Magyar Királyságának határszéli csendőrsége.

43 58 320/1912. (IV. 13.) BM.kr. op.cit.

${ }^{44}$ PARÁDI: A magyar határórizet 1867-1945.

45 1912/LXIII.tc.

${ }^{46}$ PARÁDI: Áttérés a háborús határőrizetre az első világháború elött.

${ }^{47} 5$ 047/1919. (X. 1.) ME.r. op.cit.

\section{Jegyzetekben alkalmazott röviditések:}

\section{MONOGRÁFIÁK, KISMONOGRÁFIÁK ÉS HASONLÓ JELLEGÜ KÖTETEK}

BORBÉLY - KAPY

Csizmadia

GALÁNTAI

PARÁDI: Pénzügyörség és vámhivatalok a határőrizetben.

PARÁDI: Csendőrség a határőrizetben.
- BORBÉLy Zoltán - KAPY Rezső (szerk.): A 60 éves magyar rendőrség 1881-1941. Budapest, 1942, Halász Irodalmi és Könyvkiadó Vállalat. 594 p.

- Csizmadia Andor: A magyar közigazgatás fejlődése a XVIII. századtól a tanácsrendszer létrejöttéig. Budapest, 1976, Akadémia Kiadó. 560 p. HUISBN 9630507137.

- Galántai József: A Habsburg-monarchia alkonya. Osztrák-magyar dualizmus 1867-1918. Budapest, 1985, Kossuth. 386 p. HU-ISBN 9630925893.

PARÁDI József: Pénzügyörség és vámhivatalok a határörizetben. Budapest, 2003, Tipico Design. 219 p. HU-ISBN 963762330 2./Rendvédelem a határokon a XIX-XX. században, 1./ HU-ISSN -

PARÁDI József: Csendőrség a határörizetben. Budapest, 2003, Tipico Design. 186 p. HU-ISBN 963762331 0. /Rendvédelem a határokon a XIX-XX. században, 2./ HU-ISSN - 
PARÁDI: Rendőrség a határőrizetben.

PARÁDI: A Magyar Királyi Csendörség. Az elsö magyar polgári központositott, közbiztonsági örtestület 1881-1945.

PARÁDI - SUBA — VEDÓ

\section{TANULMÁNYOK}

NAGY

PARÁDI: A dualista Magyarország határőrizeti rendszerének kialakulása.

PARÁDI: A népi demokratikus forradalom határrendőrsége 1945-1949.

PARÁDI: A polgári magyar állam első határörizeti szakszerve a Magyar Királyi Határrendörség 1906-1914.

PARÁDI: A Magyar Királyi Határrendőrség, a magyar határőrizet szakmai vezető testülete.

PARÁDI: Áttérés a háborús határőrizetre az első világháború előtt

PARÁDI: A magyar határőrizet 1867-1945.

PARÁDI: A dualizmuskori magyar rendvédelem és határörizet. A Magyar Királyi Határrendőrség.

PARÁDI: A polgári magyar rendvédelem a XIX-XX. században.

PARÁDI: A Magyar Királyi Csendőrség határőrizeti szolgálata.
PARÁDI József: Rendőrség a határörizetben. Budapest, 2003, Tipico Design. 266 p. HU-ISBN 963762332 9. /Rendvédelem a határokon a XIX-XX. században, 3./ HU-ISSN -

PARÁDI József: A Magyar Királyi Csendőrség. Az első magyar polgári központositott, közbiztonsági örtestület 1881-1945. Budapest, 2012, Szemere Bertalan Magyar Rendvédelem-történeti Tudományos Társaság. 281 p. HUISBN 978963084794 0. /A magyar rendvédelem-történet öröksége, 2./ HUISSN 2062-8447.

PARÁDi József - Suba János - Vedó Attila: A magyar-román határ és örzése 1867-1918. Budapest, 2014², Szemere Bertalan Magyar Rendvédelemtörténeti Tudományos Társaság. 172 p. HU-ISBN 978963898285 8. /A magyar rendvédelem-történet öröksége, 3./ HU-ISSN 2062-8447.

- NAGY György: A határforgalom és ellenőrzése 1945-1950 között. Rendvédelem-történeti Füzetek (Acta Historiaae Preasidii Ordinis), VI.évf. (1996) 7.sz. 68-79.p. HU-ISSN 1216-6774. A tanulmány korábbi változata 1995. október 25-én Budapesten hangzott el a Szemere Bertalan Magyar Rendvédelem-történeti Tudományos Társaság által szervezett rendvédelem-történeti tudományos konferenciasorozatnak „Háborúból diktatúrába” című VII. konferenciáján. A publikált tanulmány az előadás javított, bővített és átdolgozott változata.

PARÁDI József: A dualista Magyarország határőrizeti rendszerének kialakulása. Belügyi Szemle, XXX.évf. (1982) 10. sz. 44-51.p. HU-ISSN 0133-6738.

PARÁDI József: A népi demokratikus forradalom határrendőrsége 19451949. In ÁBEL László (szerk.): A határőrség 40 éve Budapest, 1985, Határőrség. 67-80. p. HU-ISBN -

PARÁDI József: A polgári magyar állam első határőrizeti szakszerve a Magyar Királyi Határrendörség 1906-1914. Hadtörténelmi Közlemények, CI.évf. (1986) 3.sz. 541-570. p. HU-ISSN 0017-6540.

PARÁDI József: A Magyar Királyi Határrendőrség, a magyar határörizet szakmai vezető testülete. Rendvédelem-történeti Füzetek (Acta Historiae Preasidii Ordinis), III.évf. (1993) 4.sz. 21-50.p. HU-ISSN 1216-6774. A tanulmány korábbi változata 1992. szeptember 29-én Budapesten hangzott el a Szemere Bertalan Magyar Rendvédelem-történeti Tudományos Társaság által szervezett rendvédelem-történeti tudományos konferenciasorozatnak ,A dualista Magyarország rendvédelme” című IV. konferenciáján. A publikált tanulmány az előadás javított, bővített és átdolgozott változata.

PARÁDI József: Áttérés a háborús határőrizetre az első világháború előtt. Rendvédelemtörténeti Füzetek (Acta Historiae Preasidii Ordinis), IV.évf. (1994) 5.sz. 13-17.p. HU-ISSN 1216-6774. A tanulmány korábbi változata 1993. szeptember 21-én Budapesten hangzott el a Szemere Bertalan Magyar Rendvédelem-történeti Tudományos Társaság által szervezett rendvédelemtörténeti tudományos konferenciasorozatnak a „Háború, forradalom, trianon" című V. konferenciáján. A publikált tanulmány az előadás javított, bővített és átdolgozott változata.

PARÁDI József: A magyar határörizet 1867-1945. Határőrségi Tanulmányok, (1997) 1.sz. különszáma. 11-35. p. HU-ISSN —

PARÁDI József: A dualizmuskori magyar rendvédelem és határőrizet. A Magyar Királyi Határrendőrség. Határrendészeti Tanulmányok, III.évf. (2006) 1.sz. 5-46.p. HU-ISSN 1786-2345. A tanulmány korábbi változata 2006. január 17-én Budapesten hangzott el a Szemere Bertalan Magyar Rendvédelem-történeti Tudományos Társaság és a Határörség Országos Parancsnoksága közös szervezésében megvalósított konferencián. „Az ezeréves magyar rendvédelem” címü XIV. konferenciáján. A publikált tanulmány az elöadás javított, bővített és átdolgozott változata.

PARÁDI József: A polgári magyar rendvédelem a XIX-XX. században. Rendvédelem-történeti Füzetek (Acta Historiae Preasidii Ordinis), XIX. évf. (2010) 22. sz. 60-76. p. A tanulmány korábbi változata 2008. október 10.-én Budapesten hangzott el, a Szemere Bertalan Magyar Rendvédelem-történeti Tudományos Társaság által szervezett rendvédelem-történeti tudományos konferencia-sorozatnak „Másfél évszázad rendszerváltozásainak hatásai a nemzeti rendvédelmünkre” címü XXII. Konferenciáján. A publikált tanulmány az előadás javított, bővített és átdolgozott változata.

PARÁDI József: A Magyar Királyi Csendőrség határőrizeti szolgálata. Rendvédelem-történeti Füzetek (Acta Historiae Preasidii Ordinis), XIX. évf. (2010) 22. sz. 77-91. p. A tanulmány korábbi változata 2008. október 10.-én 
PARÁDI: A csendőrség teendői az Osztrák-Magyar Monarchia Magyar királysága külső határainak őrzésében.
PARÁDI: Az Osztrák-Magyar Monarchia Magyar Királyságának határszéli csendőrsége.

\section{KÉZIRATOK}

SUBA

\section{JOGSZABÁLYOK}

Nr.150/1849.

1867/XII.tc.

1867/XVI.tc.

1870/XLII.tc.

1871/XVIII.tc.

1878/XX.tc.

1887/XXIV.tc.

1898/I.tc.

1899/XXX.tc.

1903/VII.tc.

1903/VIII.tc.

1908/XII.tc.

1912/LXIII.tc.

50 431/1891. (VII. 1.) BM.r.
Budapesten hangzott el, a Szemere Bertalan Magyar Rendvédelem-történeti Tudományos Társaság által szervezett rendvédelem-történeti tudományos konferencia-sorozatnak „Másfél évszázad rendszerváltozásainak hatásai a nemzeti rendvédelmünkre” címü XXII. Konferenciáján. A publikált tanulmány az előadás javított, bővített és átdolgozott változata.

PARÁDI József: A csendőrség teendői az Osztrák-Magyar Monarchia Magyar királysága külső határainak örzésében. Rendvédelem-történeti Füzetek (Acta Historiae Praesidii Ordinis), XXI.évf. (2011) 24.sz. 100-118.p. HUISSN 1216-6774. A tanulmány korábbi változata 2009.december 3. Budapesten hangzott el, a Szemere Bertalan Magyar Rendvédelem-történeti Tudományos Társaság által szervezett rendvédelem-történeti tudományos konferencia-sorozatnak „Csendörség Ausztria-Magyarországon, illetve Ausztriában és Magyarországon 1849-2005" címü XXIV. konferenciáján. A publikált tanulmány az előadás javított, bővített és átdolgozott változata.

PARÁDI József: Az Osztrák-Magyar Monarchia Magyar Királyságának határszéli csendörsége. Rendvédelem-történeti Füzetek (Acta Historiae Preasidii Ordinis), XXII.évf. (2012) 26.sz. 81-104.p. HU-ISSN 1216-6774. A tanulmány korábbi változata 2011. november 11-én, Budapesten hangzott el, a Szemere Bertalan Magyar Rendvédelem-történeti Tudományos Társaság által szervezett rendvédelem-történeti tudományos konferenciasorozatnak „,Militarizmus és demilitarizmus a XIX-XX. századi magyar állam rendvédelmében” címü XXV. konferenciáján. A publikált tanulmány az előadás javított, bővített és átdolgozott változata.

SuBA János: Magyarország határának kitüzése és felmérése 1921-1925 (a határmegállapitó bizottságok müködése). Kézirat, (ELTE-BTK.) doktori értekezés) Budapest, 1996.

- Nr.150/1849. Kaiserliches Patent, vom 4. marz 1849, [Császári pátens, 1849. III. 4.] Kaiserliches Patent, die Reichsverfassung für das Kaiserthum Österreich enthaltend. [Császári pátens, a birodalmi alkotmány az Osztrák Birodalom és részei számára.]

Reich- Gesetz- und Regierungsblatt, [Birodalmi törvény- és kormánylap] II.évf. (1850) 151-165.p.

- 1867/XII.tc. a magyar korona országai és az Ő Felsége uralkodása alatt álló többi országok között fennforgó közös érdekű viszonyokról, s ezek elintézésének módjáról.

— 1867/XVI.tc. a Magyar Korona országai és Ö Felsége többi királyságai és országai között kötött vám- és kereskedelmi szövetségről.

— 1870/XLII.tc. a törvényhatósági hatáskörröl.

— 1871/XVIII.tc. a községek rendezéséről.

— 1878/XX.tc. a Magyar Korona országai és Ö Felsége többi királysága és országai közötti vám- és kereskedelmi szövetségröl.

1887/XXIV.tc. az 1878/XX.tc.-be iktatott vám- és kereskedelmi szövetség meghosszabbításáról.

1898/I.tc. a vám- és bankügyeknek, valamint ezekkel összefüggő némely kérdésnek ideiglenes szabályozásáról.

1899/XXX.tc. a vám- és kereskedelmi viszonyokról és ezekkel összefüggő némely kérdésnek a rendezéséről.

— 1903/VII.tc. három új csendőr kerület felállításáról.

- 1903/VIII.tc. a határrendőrségröl.

— 1908/XII.tc. a kölcsönös kereskedelmi és forgalmi viszonyoknak az Ö Felsége uralkodása alatt álló többi országokkal való szabályozása tárgyában Budapesten 1907. év október hó 8.-án kötött szerződés beczikkelyezéséről.

1912/LXIII.tc. a háború esetére szóló kivételes hatalom szabályozásáról.

— $\quad 50$ 431/1891. (VII. 1.) BM.r. a m. kir. belügyministernek 50.431. szám alatt I. Besztercze-Naszód, II. Maros-Torda, III. Csik, IV. Háromszék, V. Brassó, VI. Fogaras, VII. Szeben, VIII. Hunyad és IX. Krassó-Szörény vármegye közönségéhez intézett rendelete, az 1888. évi XIV. törvényczikkel beczikkelyezett magyarromán határegyezmény alapján kiadott határőrizeti utasitás tárgyában. Magyarországi Rendeletek Tára, XXV.évf. (1891) I.füzet. 877-902.p.

5692/1905. (XII. 29.) ME.r.
5692/1905. (XII. 29.) ME.r. a határrendőrségröl szóló 1903/VIII.tc. életbe léptetéséről.

Magyarországi rendeletek Tára, XXXIX.évf. (1905) I.füzet. 1455.p. 
91 000/1905. (XII. 29.) BM.kr.

128 000/1906. (1907. I. 3.) BM.kr.

66 733/1910. (VII. 1.) BM.kr.

58 320/1912. (IV. 13.) BM.kr.

5 047/1919. (X. 1.) ME.r.

6 500/1931. (XI. 30.) ME.r.

145 389/1945. (VIII. 17.) BM.r.

288 009/1948. (IX. 6.) BM.r.

288 010/1948. (IX. 6.) BM.r.
91 000/1905. (XII. 29.) BM.kr. a határrendőrségről szóló 1903/VIII.tc. végrehajtásáról.

Magyarországi rendeletek Tára, XXXIX.évf. (1905) I.füzet. 1455-1541.p.

128 000/1906. (1907. I. 3.) BM.kr. szolgálati és fegyelmi szabályzat a magyar királyi határrendőrség legénysége számára. Belügyi Közlöny, XII.évf. (1907) 2.sz. 7-18.p.

- $\quad 66733 / 1910$. (VII. 1.) BM.kr. a határrendőr-altisztek hivatalos szolgálatából kifolyólag felmerülő költségek egyöntetű elszámolása és ellenörzése. Belügyi Közlöny, XV.évf. (1910) 31.sz. 290-297.p.

- 58 320/1912. (IV. 13.) BM.kr. a határrendőri külszolgálat ellátása a határrendőrségi örségek megszüntetésével.

Belügyi Közlöny, XVII.évf. (1912) 8.sz. 136-140.p.

- $\quad 5$ 047/1919. (X. 1.) ME.r. a rendőrség államosításáról. Magyarországi Rendeletek Tára, LIII.évf. (1919) I.füzet. 752-767.p.

- 6 500/1931. (XI. 30.) ME.r. a rendőrség szervezeti változásairól. Magyarországi Rendeletek Tára, LXV.évf. (1931) XII.füzet. 1533-1534.p.

- $145389 / 1945$. (VIII. 17.) BM.r. a magyar határrendőrség felállítása tárgyában. Rendörségi Közlöny, I.évf. (1945) 9.sz. 180-183.p.

— $\quad 288$ 009/1948. (IX. 6.) BM.r. a rendőrség államvédelmi osztálya középfokú hatósági szervezetének megállapítása és elnevezésének megváltoztatása. Rendörségi Közlöny, IV.évf. (1948) 19.sz. 727-728.p.

- $\quad 288$ 010/1948. (IX. 6.) BM.r. a belügyminisztérium államvédelmi hatósága jogkörének megállapítása.

Rendörségi Közlöny, IV.évf. (1948) 19.sz. 728.p.

Mellékletek jegyzéke:

I.sz. melléklet

A Magyar Királyi Határrendőrség szervezeti felépítése.

II.sz. melléklet.

A Magyar Királyi Határrendőrség rendfokozatai.

III.sz. melléklet

A határőrizetben résztvevők személyi összetétele 1913-ban.

A Magyar Királyi Határrendőrség szervezeti felépítése.

ForRás ! PARÁdI József: Rendőrség a határőrizetben. 253.p. Budapest, 2003, Tipico Design. 266 p. HU-ISBN 9637623329. /Rendvédelem a határokon a XIX-XX. században, 3./ HU-ISSN - 
A Magyar Királyi Határrendőrség rendfokozatai.

II.sz. melléklet.

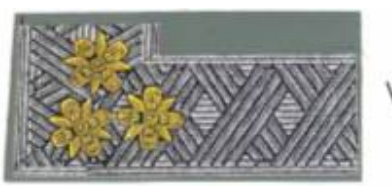

VI.FÕTANÁCSOS

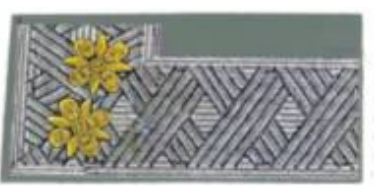

VII.TANÁCSOS

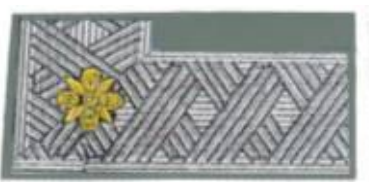

VIII.KAPITÁNY

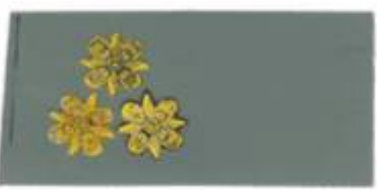

IX.FOGALMAZÓ
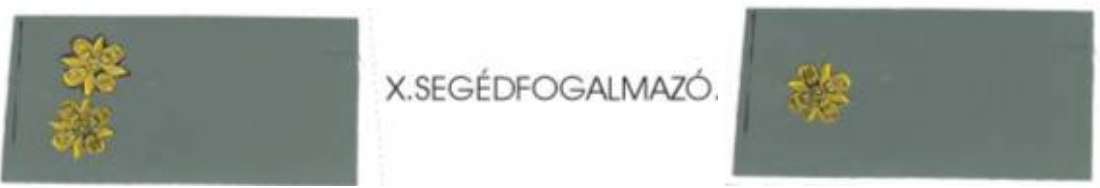

XI.FOGALMAZO GYAKORNOK

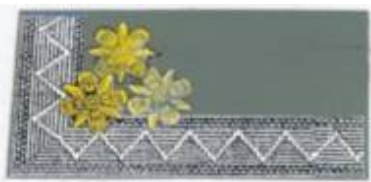

\section{ŌRMESTER}

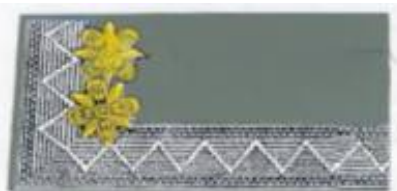

\section{O̊RSÉGVEZETó}

\section{HATÁRRENDŌR}

Megjegyzés: A római számok az érettségi vagy annál magasabb képzettséggel rendelkezők állami fizetési osztálybesorolását jelölik. A határrendőri rangokat — mivel nem katonailag szervezett fegyveres örtestület, hanem polgári fegyveres örtestület volt — nem csillagok, hanem úgynevezett csillagrózsácskák jelölték.

Forrás ! ZeIDLER Sándor: A magyar rendőri rangok fejlődéstörténete a kiegyezéstől az ezredfordulóig. 123.p. Rendvédelemtörténeti Füzetek (Acta Historiae Praesidii Ordinis) XIV.évf. (2008) 17.sz. 116-137.p. HU-ISSN 1216-6774.

A határörizetben résztvevök személyi összetétele 1913-ban.

III.sz. melléklet

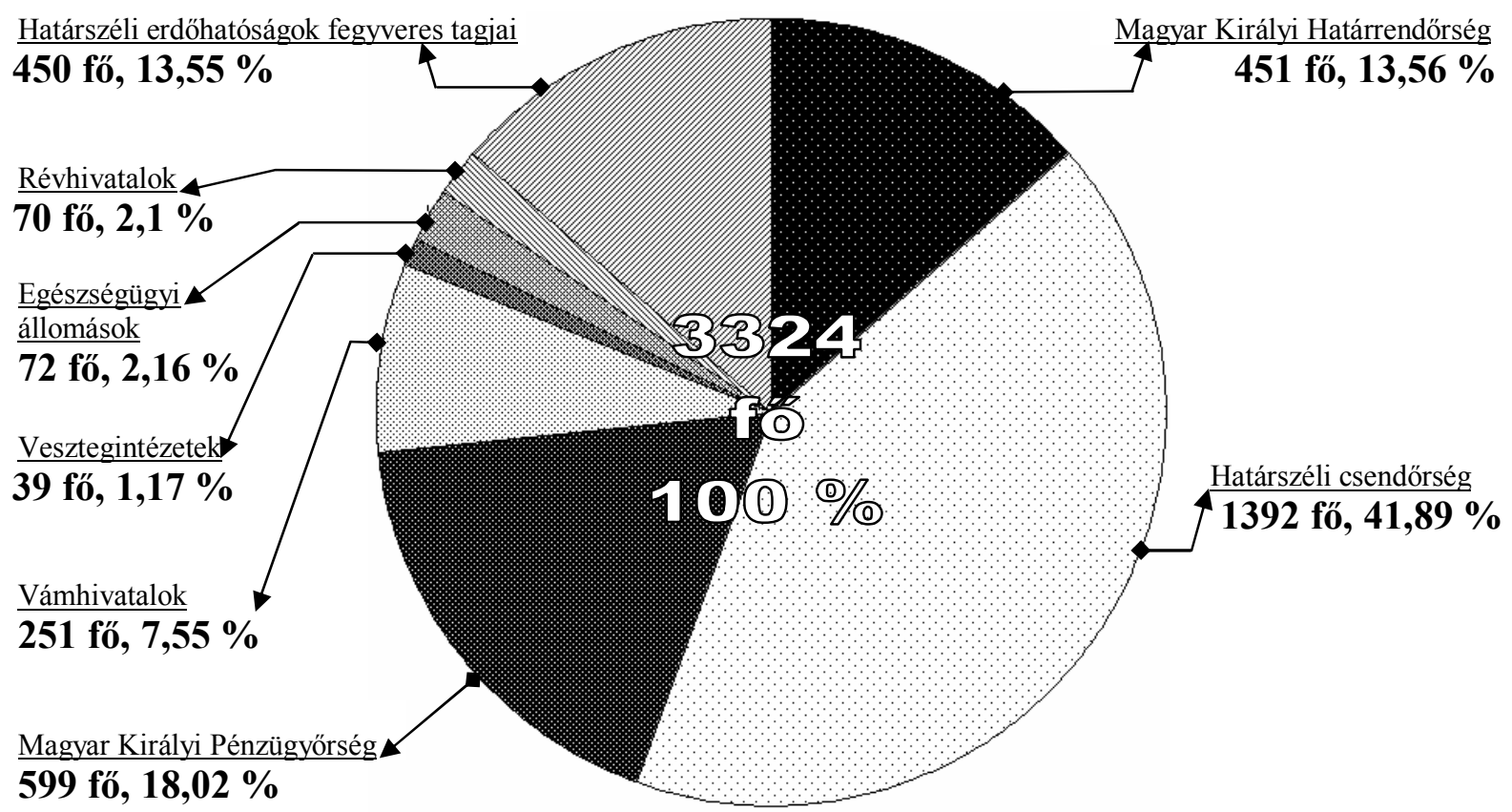

ForRás ! PARÁDI József: Rendőrség a határörizetben. 252.p. Budapest, 2003, Tipico Design. 266 p. HU-ISBN 9637623329. /Rendvédelem a határokon a XIX-XX. században, 3./ HU-ISSN - 